\title{
An Eye for Detail: the Dallard years
}

\author{
Christine McCarthy, Interior Architecture Programme, Te Herenga Waka I Victoria University Wellington
}

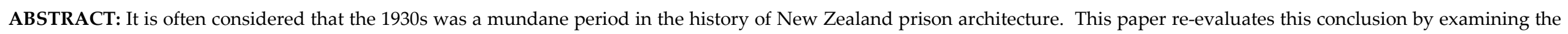
specific aspect of prison interior architecture and the incremental changes that occurred to prison buildings during this period of New Zealand's prison history.

\section{Introduction}

The 1930s are the Dallard years of New Zealand prisons. Berkeley Lionel Scudamore Dallard, the Controller General of Prisons 1926-49, was in charge of New Zealand prisons for the whole decade of the 1930s. Newbold writes that: "there was little in the way of penal development in the 23 years that Dallard was in charge of prisons." 1 It is true the Depression limited much of what might have happened, but this evaluation is not completely borne out when examining aspects of interior architecture.

Dallard, an accountant, and seemingly a micromanager, understood details. Newbold's account of Dallard's visit to Mount Eden should have been a clue. Newbold writes:

His [BLS Dallard] first reaction to Mt. Eden was of repugnance. The stone cells and high, slit windows remined him of the works of Dumas, and he disdained the smell of sweat, unwashed bodies. He promptly

\footnotetext{
${ }^{1}$ Newbold "Dallard, Berkeley Lionel Scudamore" n.p.
}

organized carbolic soap to be made up and distributed to all inmates, and he increased the number of showers permitted from one to two each week. He had air vents fitted to the cells, with floorboards installed in some of them. He ordered that bedsheets be distributed to all prisoners and he provided an oil-burning stone for use in the prison kitchen. ${ }^{2}$

\section{Maintenance and Repair}

Given the economic context, it is unsurprising that many changes to interior architecture were in the realm of maintenance and repair. Themes include the use of prisoners for building repair and maintenance (including cleaning and painting), ${ }^{3}$ and the upgrading of

\footnotetext{
${ }^{2}$ Newbold Punishment $\mathcal{E}$ Politics p 6.

${ }^{3}$ For example: Dunlop, Waikeria Borstal Institution (1930) p 25; Leggett, Paparua Prison (1932) p 16; Dickison, Auckland Prison (1932) p 12; Dickison, Auckland Prison (1933) p 10; Richardson, Gisborne Prison (1933) pp 13-14; Ayling, Greymouth Prison (1933) p 12; Leggett, Paparua Prison (1933) pp 13-14; McGrath, Waikune Prison (1933) p 15; Dickison, Auckland Prison (1934) p 11; Robinson, Greymouth Prison (1934) p 13; Dickison, Auckland Prison (1935) p 10; Robinson, Greymouth Prison (1935) p 12; Dunlop, Waikeria Borstal Institution (1935) p 30; Dickison, Auckland Prison (1935)
}

electrical systems due to new regulations. ${ }^{4}$ At Mount Crawford "rewiring and grouping of the hot-points" was carried out, ${ }^{5}$ at Auckland, the whole of the prison electrical system was "overhauled" in 1931, ${ }^{6}$ and at Waikeria: "[t]he electric-light system was also improved by rewiring and changing over from the 110 voltage to 230 voltage."7 Also at Auckland, "the work of changing over from direct to alternating current was put in hand and completed early in the year [1932], and has resulted in a very considerable saving to the Department."8

Significant also work related to plumbing and sewerage systems, including new pipe connections to bring water to prisons, ${ }^{9}$

p 18; Leggett, Paparua Prison (1936) p 22.

${ }^{4}$ Pollock, Invercargill Borstal Institution (1933) p 20; Ching, Wanganui Prison (1936) p 24.

${ }^{5}$ Down, Wellington Prison (1930) p 18.

${ }^{6}$ Dickison, Auckland Prison (1932) p 12.

${ }^{7}$ Dunlop, Waikeria Borstal Institution (1930) p 25.

${ }^{8}$ Dickison, Auckland Prison (1933) p 9.

${ }^{9}$ Down, Wellington Prison (1930) p 19. 
installation of septic tanks, ${ }^{10}$ new lavatories were installed with "a new system of sewer drainage with water flushing,"11 and new shower-baths, ${ }^{12}$ which, at Waikeria, would enable prisoners to have "at least two hot baths a week and a cold shower daily, if deemed advisable by the Medical Officer,"13 and a water-heater and additional showerbaths installed at New Plymouth. ${ }^{14}$

An exception to generic references to repair included responses to earthquake damage, such as to Wanganui Prison from the 16 June 1929 Buller earthquake. The gaoler (E Ching) described the damage as "considerable" affecting brickwork in two officers' cottages and the laundry. ${ }^{15}$ The 2nd February 1931 Hawke's Bay earthquake affected both the Napier and Gisborne Prisons - though at Gisborne the damage mainly affected one chimney. ${ }^{16}$ Napier prison, in contrast, experienced damage to foundations, plumbing and sewerage systems, the kitchen

${ }^{10}$ Pollock, Invercargill Borstal Institution (1930) p 24;

Dunlop, Waikeria Borstal Institution (1930) p 25.

${ }^{11}$ Dunlop, Waikeria Borstal Institution (1930) p 25.

${ }^{12}$ Down, Wellington Prison (1930) pp 19, 20.

${ }^{13}$ Dunlop, Waikeria Borstal Institution (1934) p 13.

${ }^{14}$ Dineen, New Plymouth Prison (1936) p 22.

${ }^{15}$ Ching, Wanganui Prison (1930) p 17.

${ }^{16}$ Richardson, Gisborne Prison (1932) p 13. and yards, and "the division walls inside the prison were demolished."17 Temporary latrines and a kitchen were erected. ${ }^{18}$ The No 1 Warder's cottage was "completely shaken off its foundations," and "[t]he chimneys of all the cottages were brought down, and other damage caused."19 The repairs included wallpapering, ${ }^{20}$ and took longer than a year, the floors of the exercise yards being patched in 1932. ${ }^{21}$ Continuing shocks caused lights to fail, and the provision of hurricane lamps for emergencies. ${ }^{22}$

\section{"New" building}

But new building of a sort did go on. Warder's cottages were repaired, renovated, maintained, papered and painted, ${ }^{23}$ had new rooms added, ${ }^{24}$ were connected to water supply, ${ }^{25}$ had electrical work done, ${ }^{26}$ and fire

\footnotetext{
${ }^{17}$ Stocker, Napier Prison (1932) p 15.

${ }^{18}$ Stocker, Napier Prison (1932) p 15.

${ }^{19}$ Stocker, Napier Prison (1932) p 15.

${ }^{20}$ Stocker, Napier Prison (1932) p 15.

${ }^{21}$ Stocker, Napier Prison (1933) p 12.

22 Stocker, Napier Prison (1933) p 13.

${ }^{23}$ For example: Cook, Napier Prison (1930) p 14; Down,

Wellington Prison (1930) p 19; Stocker, Napier Prison

(1932) p 15; Richardson, Gisborne Prison (1935) p 12;

Dineen, New Plymouth Prison (1935) p 13.

${ }^{24}$ Down, Wellington Prison (1930) p 19.

${ }^{25}$ Down, Wellington Prison (1930) p 19; Blain, Wi Tako
}

escapes added. ${ }^{27}$ But new staff cottages were also built at Mount Crawford,28 and at Waikune "to cope with the housing difficulty experienced by the married members of the staff," 29 while, at Waikeria, "machinery was removed from the old power-house building" in order to convert it into a four-roomed cottage for a married officer. ${ }^{30}$

Materials from demolished buildings were reused in new buildings (e.g. materials from Ordinance buildings neighbouring Mount Eden were used as payment to the prison for its dismantling; ${ }^{31}$ materials from the demolition of prison buildings at the Terrace prison were used at Mount Crawford; ${ }^{32}$ the old store from the Terrace was relocated to $W_{\overline{1}}$ Tako Prison "to be used as a wool-store and shearing shed"33). Materials from general

Prison (1930) p 20.

${ }^{26}$ Down, Wellington Prison (1930) p 19; McGrath,

Waikune Prison (1933) p 15.

${ }^{27}$ Dickison, Auckland Prison (1933) p 9.

${ }^{28}$ Down, Wellington Prison (1930) p 19.

${ }^{29}$ McGrath, Waikune Prison (1933) p 15.

${ }^{30}$ Dunlop, Waikeria Borstal Institution (1933) p 21;

Dunlop, Waikeria Borstal Institution (1934) p 22.

${ }^{31}$ Dickison, Auckland Prison (1930) p 11.

${ }^{32}$ Down, Wellington Prison (1930) p 18.

${ }^{33}$ Down, Wellington Prison (1930) p 19; also Blain, Wi

Tako Prison, Heretaunga (1930) p 20. 
maintenance supplies, rather than specificallybought materials, were used to build structures, ${ }^{34}$ for example, a steading building at Paparua was constructed from old girder irons and concrete blocks. ${ }^{35}$ There was also adaptive reuse of buildings (e.g. former Defence Department buildings were converted into a tobacco factory at Auckland Prison using prison labour ${ }^{36}$ ) and new buildings accommodated multiple uses (e.g. the $20 \mathrm{ft} \times 18 \mathrm{ft}$ drying room at Rangipo was also used as a chapel and for concerts ${ }^{37}$ ).

There was an emphasis on well-lit and wellventilated spaces. At Mount Crawford, for example additional ventilation was provided for cells, and a grille was "placed across the passage to allow for a greater volume of fresh air." 38 At Waikeria a clay bank was removed "affording greater access of light and air to that side of the main corridor and cell-house building." 39 Cell block windows were also widened, "allowing more fresh air through the

\footnotetext{
${ }^{34}$ Dickison, Auckland Prison (1930) p 11.

${ }^{35}$ Leggett, Paparua Prison (1936) p 22.

${ }^{36}$ Dickison, Auckland Prison (1933) p 9.

${ }^{37}$ Banks, Rangipo Prison p 17.

${ }^{38}$ Down, Wellington Prison (1930) p 18.

${ }^{39}$ Dunlop, Waikeria Borstal Institution (1930) p 25.
}

building"40 (e.g. Mount Crawford, Waikeria). When Addington was renovated in 1936, the lowered ceiling was credited with "giving the inside of the building a warmer and more pleasing appearance."41 What would have been concrete floors in cells were now timber (e.g. Mount Crawford ${ }^{42}$ ). The prison superintendent at Mount Crawford even reported that, in windows, "ribbed glass [was] replaced by plain."43 At Invercargill, existing windows were altered to ensure aesthetic consistency with a new addition. ${ }^{44}$ Small details appear to count.

\section{Classification}

Dallard was clear about the relationship between interior architecture and prisoner classification, saying that:

"the question of the housing of prisoners is closely allied to the matter of occupation and classification. The finer the degree of classification and segregation means the larger the expense in building suitable accommodation ... The existing prison buildings - even those recently constructed - are unsatisfactory for the purpose of classification and segregation of the various classes of

\footnotetext{
${ }^{40}$ Dunlop, Waikeria Borstal Institution (1930) p 25.

${ }^{41}$ Dallard, The Controller-General of Prisons (1937) p 8.

${ }^{42}$ Down, Wellington Prison (1930) p 18.

${ }^{43}$ Down, Wellington Prison (1930) p 18.

${ }^{44}$ Pollock, Invercargill Borstal Institution (1930) p 24.
}

prisoners." 45

It was perhaps this thinking that led Dallard to propose separate institutions for each class of prisoner, rather than attempting classification within each institution.

He proposed five different institutions corresponding with different classes of prisoners - the borstals at Invercargill, Waikeria, and Point Halswell for the young, the prison farms for the accidental and trustworthy prisoner, Mount Eden prison for long sentence prisoners, Wanganui Prison for the odd and senile, and New Plymouth for sex offenders. ${ }^{46} \mathrm{He}$ also referred to the need for a "special colony" for prisoners known as "criminal lunatics," who, while not certifiable "would be a menace to public safety if at large, and a danger to other patients if in an ordinary mental hospital." ${ }^{47}$ There still remained separation between accused and sentenced prisoners within institutions. Leggett, for example, writing of Paparua Prison, referred to the provision of an

\footnotetext{
${ }^{45}$ Dallard quoted, Pratt Punishment in a Perfect Society $\mathrm{p}$ 228.

${ }^{46}$ Dallard, The Controller-General of Prisons (1936) pp 78.

${ }^{47}$ Dallard, The Controller-General of Prisons (1932) p 9.
} 
additional exercise yard for remand prisoners enabling "better segregation and control."48 Likewise, there was a solitary-division at Auckland Prison. In 1931 "a protective covering of expanded metal was placed over [the associated exercise yard]," which Dickison described as an innovation, explaining that its installation had "obviated the previous necessity of having an officer in attendance on the prisoners whilst in this yard." 49

Dallard's conception of classification operating at the institutional level might also be the reason why the 1930s saw congregate or association cells seemingly become more prevalent. Derby states that:

By the 1930s ... a number of communal cells, known as association cells, had been created. These housed from three to 12 men each ... and inmates with good-conduct records competed fiercely for the opportunity to transfer to them. One, known as the ... "old men's home," was described by the Herald as reserved for "aged derelicts whose place is not really prison. They do no work, but potter about." 50

As an example of Dallard's thinking of

${ }^{48}$ Leggett, Paparua Prison (1930) p 15.

${ }^{49}$ Dickison, Auckland Prison (1932) p 12.

${ }^{50}$ Derby Rock College pp 159-160. institutional classification affecting the internal environment of the prison, he describes Wanganui, housing physicallyweaker prisoners and that

a special milieu suited to their physical condition has been devised. The living-conditions have been planned on the basis of a large well-lit and well-ventilated common dormitory equipped with hospital beds lavatories (water flushed) are conveniently arranged.51

He had earlier (1937) noted at Wanganui, that "Instead of the usual system of individual cells the prisoners are in association ... [enabling] the wants of those to be readily attended to who are able only to help themselves with difficulty."

By the end of the decade, a more relaxed attitude to cell interiors was also apparent, with "all prisoners [at Mount Eden] .. permitted to have flowers and pictures in their cells" by 1939.52 At Waikeria, "[p]edestals, cabinets, and floor-rugs have been provided in the cubicles." 53

\section{Ephemeral interiors}

A significant addition to prison life in the

${ }^{51}$ Dallard, The Controller-General of Prisons (1939) p 5.

${ }^{52}$ Derby Rock College p 172.

${ }^{53}$ Dunlop, Waikeria Borstal Institution (1939) p 21. 1930s was the installation of wireless plants and the showing of magic lanterns slides and films. These lectures and entertainments were justified in various ways. The New Plymouth superintendent stated that the prisoners at New Plymouth, had a

peculiar type of mentality ... apt to become very depressed and morose under ordinary prison routine. To help to overcome this difficulty and with the idea of giving these prisoners plenty of good clean bright subjects to think and talk about, more entertainments and lectures are given here than would perhaps be permitted at an ordinary prison. ${ }^{54}$

More generally, Dallard stated that "concerts and other entertainments of a cultural nature are held from time to time at the various institutions as a means of relaxation and recreation." 55 In his 1937 report, he referred to "cultural reasons" and the prevention of "mental retrogression." 56

Mr Haseldine provided radio equipment to Invercargill Borstal in 1929,57 and $\mathrm{Mr} \mathrm{HE}$ Frederick of Raetihi raised funds "to donate a radio receiving set for use of the inmates"58 at

${ }^{54}$ Dineen, New Plymouth Prison (1933) p 13.

${ }^{55}$ Dallard, The Controller-General of Prisons (1936) p 5.

${ }^{56}$ Dallard, The Controller-General of Prisons (1937) p 7.

${ }^{57}$ Pollock, Invercargill Borstal Institution (1930) p 22.

${ }^{58}$ McGrath, Waikune Prison (1933) p 14. 
Waikune. In his annual report, McGrath, the Officer in Charge at Waikune, noted: "[o]ur isolated position makes the wireless receiving set a very acceptable gift." ${ }^{59}$ Wireless plants at prisons made concerts, religious services and educational resources available to prisoners, and Dallard noted that in 1935 that "at all the Borstals and most of the other institutions wireless has been installed."60 Later in the decade, following the election of the first Labour government, "daily broadcasting of radio programmes through speakers in the exercise yards and via headphones in the cells of long-serving inmates" was introduced. ${ }^{61}$

Films were shown in prisons from the beginning of the decade. Annual reports suggest cinema in prisons from at least 1929, though this appears not to have been a consistent experience, Derby noting of Mount Eden, that the first film was shown there in 1931. ${ }^{62}$ This was Balaclava, an historic epic of the Charge of the Light Brigade, and shown to 400 men in the prison chapel. ${ }^{63}$ Derby notes that: "Many of the men had been admitted to

${ }^{59}$ McGrath, Waikune Prison (1933) p 14.

${ }^{60}$ Dallard, The Controller-General of Prisons (1936) p 5.

${ }^{61}$ Derby Rock College p 172

${ }^{62}$ Derby Rock College p 162.

${ }^{63}$ Derby Rock College p 162. the prison during the silent movie era and had never before seen a "talkie"."64 The reasons for the choice of Balaclava are unclear. Its subject is an army officer falsely accused of murder. More usually, movies shown seem to have topics such as New Zealand bird and animal life. ${ }^{65}$

Often slides and film showings were sanctioned as educational, ${ }^{66}$ and access to equipment sometimes relied on the goodwill of individuals. The YMCA, for example, lent a marquee and "cinema oufit" to the Invercargill Borstal association class camp at Otatara, with films being lent by Invercargill picture-theatres. ${ }^{67}$ This was not unusual. Most mentions of cinema and lantern slides in prison include acknowledgement of a varied range of organisations such as the Auckland Institute and Museum, ${ }^{68}$ the Canadian Government Trade Commissioner, ${ }^{69}$ the Publicity Department of the New Zealand Government,70 and Imperial Airways, Ltd,

${ }^{64}$ Derby Rock College p 162.

${ }^{65}$ Dunlop, Waikeria Borstal Institution (1935) p 21.

${ }^{66}$ e.g. Dunlop, Waikeria Borstal Institution (1936) p 30.

${ }^{67}$ Pollock, Invercargill Borstal Institution (1930) p 22.

${ }^{68}$ Dunlop, Waikeria Borstal Institution (1935) p 21;

Dunlop, Waikeria Borstal Institution (1936) p 30.

${ }^{69}$ Dunlop, Waikeria Borstal Institution (1936) p 30.

${ }^{70}$ Dunlop, Waikeria Borstal Institution (1936) p 30
England. ${ }^{71}$ One of the guest presenters of a motion-picture film shown at Wī Tako Prison, was Dallard, the Controller-General, himself. ${ }^{72}$

\section{Conclusion}

As the decade progressed spending on interior architecture increased. The accumulation of details, seemingly dismissed in previous prison histories of New Zealand, begins to build to something greater. It is like the experience of seeing Michael Snow's 1971 Le Région Centrale, filmed over five days on a deserted mountain in North Quebec. After three hours of grit, sky, and then a bit more slow-moving hillside, over and over again, the solidity of earth diminishes into an ephemeral and magical hessian waving in the breeze.

Dallard's penal efforts might not result in any moving aesthetic majesty, but after a decade of paperwork, he presents the strategy which has underpinned these seemingly ad hoc and unconnected actions of Depression pennypinched building. The details we are already familiar with are re-presented as a deliberate composition forming a larger strategy. Interior architecture - the design of the

\footnotetext{
${ }^{71}$ Dunlop, Waikeria Borstal Institution (1936) p 30.

${ }^{72}$ Jordan, Wi Tako Prison (1939) p 15.
} 
environment the prisoners are to inhabit - is number 3 in a list of 7 priorities.

\section{His 1939 report stated:}

In view of the approach of the Centennial it may be an opportune time to outline some of the improvements that have been effected in prison-management. ... The policy the Department has striven to follow has been one of cautious progressiveness. In dealing with offenders against society it has always been considered unwise to proceed too far in advance of public opinion. Thus the many improvements that have been made have not been effected dramatically, but by a steady evolutionary process of experimentation designed to keep the system in accord with developments overseas, and at the same time making due allowances and modifications to suit local requirements. ${ }^{73}$

Dallard was interested in design with a little "d" - the kind of design that doesn't make it into history books, and the kind of design that no one seems to notice. Its very incrementality means that change actually happens. It is a design strategy more interested in making a difference than making historical headlines and being seen. That might account for the lack of historians seeing it.

${ }^{73}$ Dallard, The Controller-General of Prisons (1939) p 4. 


\section{REFERENCES}

Ayling, W., Greymouth Prison (Gaoler, Mr. W. Ayling) Appendices to the Journals of the House of Representatives Wellington: Government Printer, 1933. H-20:11-12.

Banks, A. Rangipo Prison (Officer in Charge, Mr. A. Banks) Appendices to the Journals of the House of Representatives Wellington: Government Printer, 1930. H-20:17.

Banks, T. Hautu [Tongariro] Prison (Officer in Charge, Mr. T. Banks) Appendices to the Journals of the House of Representatives Wellington: Government Printer, 1936. H-20:20-21.

Blain, D. Wi Tako Prison, Heretaunga (Superintendent, Mr. D. Blain) Appendices to the Journals of the House of Representatives Wellington: Government Printer, 1930. H-20:19-20.

Ching, E., Wanganui Prison (Gaoler, Mr. E. Ching) Appendices to the Journals of the House of Representatives Wellington: Government Printer, 1930. H-20:17.

Ching, E., Wanganui Prison (Gaoler, Mr. E. Ching) Appendices to the Journals of the House of Representatives Wellington: Government Printer, 1932. H-20:17.

Ching, E., Wanganui Prison (Gaoler, Mr. E. Ching) Appendices to the Journals of the House of Representatives Wellington: Government Printer, 1933. H-20:15.

Ching, E., Wanganui Prison (Gaoler, Mr. E. Ching) Appendices to the Journals of the House of Representatives Wellington: Government Printer, 1934. H-20:16.

Ching, E., Wanganui Prison (Gaoler, Mr. E. Ching) Appendices to the Journals of the House of Representatives Wellington: Government Printer, 1936. H-20:24.

Cook, W.R., Napier Prison (Gaoler, Mr. W.R. Cook) Appendices to the Journals of the House of Representatives Wellington: Government
Printer, 1930. H-20 pp. 13-14

Dallard, B.L., The Controller-General of Prisons to the Hon. the Minister in Charge of the Prisons Department Appendices to the Journals of the House of Representatives Wellington, 1930. H-20:1-9.

Dallard, B.L., The Controller-General of Prisons to the Hon. the Minister in Charge of the Prisons Department Appendices to the Journals of the House of Representatives Wellington, 1931. H-20:1-6.

Dallard, B.L., The Controller-General of Prisons to the Hon. the Minister in Charge of the Prisons Department Appendices to the Journals of the House of Representatives Wellington, 1932. H-20:1-10

Dallard, B.L., The Controller-General of Prisons to the Hon. the Minister in Charge of the Prisons Department Appendices to the Journals of the House of Representatives Wellington, 1933. H-20:1-7.

Dallard, B.L., The Controller-General of Prisons to the Hon. the Minister in Charge of the Prisons Department Appendices to the Journals of the House of Representatives Wellington, 1936. H-20:1-16.

Dallard, B.L., The Controller-General of Prisons to the Hon. the Minister of Justice Appendices to the Journals of the House of Representatives Wellington: Government Printer, 1937. H-20:1-10.

Dallard, B.L., The Controller-General of Prisons to the Hon. the Minister of Justice Appendices to the Journals of the House of Representatives Wellington: Government Printer, 1939. H-20:1-7.

Derby, Mark Rock College: An unofficial history of Mount Eden Prison Auckland: Massey University Press, 2020.

Dickison, J., Auckland Prison (Superintendent, Mr. J. Dickison) Appendices to the Journals of the House of Representatives Wellington: Government Printer, 1930. H-20:11-13.

Dickison, J. Auckland Prison (Superintendent, Mr. J. Dickison) Appendices to the Journals of the House of Representatives Wellington: Government 
Printer, 1932. H-20:11-13.

Dickison, J., Auckland Prison (Superintendent, Mr. J. Dickison) Appendices to the Journals of the House of Representatives Wellington: Government Printer, 1933. H-20:9-11.

Dickison, J., Auckland Prison (Superintendent, Mr. J. Dickison) Appendices to the Journals of the House of Representatives Wellington: Government Printer, 1934. H-20:11-13.

Dickison, J., Auckland Prison (Superintendent, Mr. J. Dickison) Appendices to the Journals of the House of Representatives Wellington: Government Printer, 1935. H-20:10-12.

Dickison, J., Auckland Prison (Superintendent, Mr. J. Dickison) Appendices to the Journals of the House of Representatives Wellington: Government Printer, 1936. H-20:18-19.

Dineen, W., New Plymouth Prison (Superintendent, Mr. W. Dineen) Appendices to the Journals of the House of Representatives Wellington: Government Printer, 1933. H-20:13.

Dineen, W., New Plymouth Prison (Superintendent, Mr. W. Dineen) Appendices to the Journals of the House of Representatives Wellington: Government Printer, 1935. H-20:13.

Dineen, W., New Plymouth Prison (Superintendent, Mr. W. Dineen) Appendices to the Journals of the House of Representatives Wellington: Government Printer, 1936. H-20:21-22.

Down, J. Wellington Prison (Superintendent, Mr. J. Down) Appendices to the Journals of the House of Representatives Wellington: Government Printer, 1930. H-20:18-19

Dunlop, D., Waikeria Borstal Institution (Te Awamutu). (Superintendent, Mr. D. Dunlop) Appendices to the Journals of the House of Representatives Wellington: Government Printer, 1930. H-20:24-26.

Dunlop, D., Waikeria Borstal Institution (Te Awamutu). (Superintendent, Mr. D. Dunlop) Appendices to the Journals of the House of Representatives
Wellington: Government Printer, 1933. H-20:20-22.

Dunlop, D., Waikeria Borstal Institution (Te Awamutu). (Superintendent, Mr. D. Dunlop) Appendices to the Journals of the House of Representatives Wellington: Government Printer, 1934. H-20:20-23.

Dunlop, D., Waikeria Borstal Institution (Te Awamutu). (Superintendent, Mr. D. Dunlop) Appendices to the Journals of the House of Representatives Wellington: Government Printer, 1935. H-20:21.

Dunlop, D., Waikeria Borstal Institution (Te Awamutu). (Superintendent, Mr. D. Dunlop) Appendices to the Journals of the House of Representatives Wellington: Government Printer, 1936. H-20:29-31.

Dunlop, D., Waikeria Borstal Institution (Te Awamutu). (Superintendent, Mr. D. Dunlop) Appendices to the Journals of the House of Representatives Wellington: Government Printer, 1939. H-20:19-21.

Jordan, A. St, P., Wi Tako Prison, Heretaunga (Superintendent, Mr. A. St. P. Jordan) Appendices to the Journals of the House of Representatives Wellington: Government Printer, 1939. H-20:15.

Leggett, W.T., Paparua Prison (Superintendent, Mr. W.T. Leggett) Appendices to the Journals of the House of Representatives Wellington: Government Printer, 1930. H-20:15-16.

Leggett, W.T., Paparua Prison (Superintendent, Mr. W.T. Leggett) Appendices to the Journals of the House of Representatives Wellington: Government Printer, 1931. H-20:8.

Leggett, W.T., Paparua Prison (Superintendent, Mr. W.T. Leggett) Appendices to the Journals of the House of Representatives Wellington: Government Printer, 1932. H-20:16.

Leggett, W.T., Paparua Prison (Superintendent, Mr. W.T. Leggett) Appendices to the Journals of the House of Representatives Wellington: Government Printer, 1933. H-20:13-14.

Leggett, W.T., Paparua Prison (Superintendent, Mr. W.T. Leggett) Appendices to the Journals of the House of Representatives Wellington: 
Government Printer, 1936. H-20:22-23

McGrath, P. Waikune Prison (Road-constructing Camp), Erua (Officer in Charge, Mr. P. McGrath) Appendices to the Journals of the House of Representatives Wellington: Government Printer, 1933. H-20:14-15.

Mackintosh, D.A. Inspector of Prisons to the Controller-General of Prisons Appendices to the Journals of the House of Representatives Wellington: Government Printer, 1930. H-20:9-10.

Mackintosh, D.A. Inspector of Prisons to the Controller-General of Prisons Appendices to the Journals of the House of Representatives Wellington: Government Printer, 1933. H-20:7.

Mackintosh, D.A. Chief Inspector of Prisons and Borstals to the Controller-General Appendices to the Journals of the House of Representatives Wellington: Government Printer, 1934. H-20:10.

Newbold, Greg "Dallard, Berkeley Lionel Scudamore" Te Ara: The Encyclopedia of New Zealand (1998)

https://teara.govt.nz/en/biographies/4d1/dallard-berkeley-lionelscudamore

Newbold, Greg Punishment \& Politics: The Maximum Security Prison in New Zealand Auckland: Otago University Press, 1989.

Newbold, Greg The Problem of Prisons: correction reform in New Zealand since 1840 Wellington: Dunmore Publishing, 2007.

Pollock, C.G.L., Invercargill Borstal Institution (Superintendent, Mr. C.G.L. Pollock) Appendices to the Journals of the House of Representatives Wellington: Government Printer, 1930. H-20: 21-24.

Pollock, C.G.L., Invercargill Borstal Institution (Superintendent, Mr. C.G.L. Pollock) Appendices to the Journals of the House of Representatives Wellington: Government Printer, 1933. H-20: 17-20.

Pratt, John Punishment in a Perfect Society: the New Zealand Penal System 1840-1939 Wellington: Victoria University, 1992.

Richardson, H.N., Gisborne Prison (Gaoler, Mr. H.N. Richardson)
Appendices to the Journals of the House of Representatives Wellington: Government Printer, 1932. H-20:13.

Richardson, H.N., Gisborne Prison (Gaoler, Mr. H.N. Richardson) Appendices to the Journals of the House of Representatives Wellington: Government Printer, 1933. H-20:11.

Richardson, H.N., Gisborne Prison (Gaoler, Mr. H.N. Richardson) Appendices to the Journals of the House of Representatives Wellington: Government Printer, 1935. H-20:12.

Robinson, H., Greymouth Prison (Gaoler, Mr. H. Robinson) Appendices to the Journals of the House of Representatives Wellington: Government Printer, 1934. H-20:13.

Robinson, H., Greymouth Prison (Gaoler, Mr. H. Robinson Appendices to the Journals of the House of Representatives Wellington: Government Printer, 1935. H-20:12.

Stocker, T., Napier Prison (Gaoler, Mr. T. Stocker) Appendices to the Journals of the House of Representatives Wellington: Government Printer, 1932. H-20:14-15.

Stocker, T., Napier Prison (Gaoler, Mr. T. Stocker) Appendices to the Journals of the House of Representatives Wellington: Government Printer, 1933. H-20: 12-13.

Stocker, T., Napier Prison (Gaoler, Mr. T. Stocker) Appendices to the Journals of the House of Representatives Wellington: Government Printer, 1934. H-20: 13-14.

Stocker, T., Napier Prison (Gaoler, Mr. T. Stocker) Appendices to the Journals of the House of Representatives Wellington: Government Printer, 1936. H-20: 21. 